\title{
ERP Components Associated with Locality Dependency of Time References between Young and Elderly Adults
}

\author{
Jeein Kim, Jee Eun Sung, Soo Eun Lee, Hyun Sub Sim \\ Department of Communication Disorders, Ewha Womans University, Seoul, Korea
}

Correspondence: Jee Eun Sung, PhD Department of Communication Disorders, Ewha Womans University, 52 Ewhayeodae-gil, Seodamun-gu, Seoul 03760, Korea

Tel: $+82-2-3277-2208$

Fax: +82-2-3277-2122

E-mail: jeesung@ewha.ac.kr

Received: October 10, 2017

Revised: January 22, 2018

Accepted: January 29, 2018

This work was supported by the Ministry of Education of the Republic of Korea and the National Research Foundation of Korea (No. NRF-2017R1A2B4006604).
Objectives: The purpose of this study was to investigate age-related differences in eventrelated potential (ERP) components associated with locality effects on processing time references between younger and elderly adults using a verb-final language. Methods: A total of 32 participants participated in the study. The locality was manipulated by the distance between time-adverbs and verbs with short- and long-distance conditions. The tense agreement between time-adverbs and tense markers in the verbs was manipulated by varying the levels of agreement, resulting in a total of four conditions as a function of the distance and tense agreement. Results: Behavioral results revealed that the elderly group showed significantly lower accuracy and slower reaction time (RT) than the younger group. Longer distance and disagreement of tense references elicited lower accuracy and longer RTs. Group differences emerged in 600-800 ms, with the elderly group presenting reduced amplitude compared to the younger adults. Conclusion: Elderly adults demonstrated greater difficulties in integrating syntactic components required for processing tense references over the distance. Attenuated P600 components in the elderly group indicate that it is likely to be attributed to reduced cognitive capacity and slowed processing speed in elderly adults.

Keywords: Aging, Tense agreement, Distance, Event related potential (ERP)
노화가 진행됨에 따라 주의 집중력, 기억력, 정보처리 능력 등과 같은 인지 능력의 감퇴하며, 이는 언어 이해 및 표현 능력에 영향을 주는 것으로 보고되어 왔다(Burke \& MacKay, 1997; Stine-Morrow, Ryan, \& Leonard, 2000; Zurif, Swinney, Prather, Wingfield, \& Brownell, 1995). 이러한 인지 능력 저하에 따른 언어 능력의 변 화를 측정하는 것은 단어 또는 문장 등 다양한 수준에서 다루어질 수 있으며, 그 중 문장 처리 관련 연구는 통사 및 의미 통합 과정을 다양하게 파악할 수 있다는 점에서 의미가 있다. 하지만, 한국어를 사용하는 노년층을 대상으로 노화에 따라 실시간 문장 처리 과정 (real-time sentence processing)을 살펴보는 연구는 매우 제한적이 다. 본 연구는 문장 처리 과정 중에서도, 시제 표지의 위치에 따른 노년층과 청년층 간의 실시간 문장 처리 과정에서 어떠한 변화가 나타나는지를 사건관련전위(event-related potentials, ERP) 측정
방법을 사용하여 살펴보고자 한다.

시제(tense)는 기본적으로 사건 발생의 위상과 시간에 대한 것으 로, 개인을 둘러싸는 상황 및 사건에 대한 인지와 해석에 중요한 역 할을 하는 언어적 요소이다(Comrie, 1985). 동사의 시제 표지(tense marker)를 보다 정확하게 이해하고 표현하기 위해서는 시제와 관 련된 동사의 통사적인 규칙성과 시간 부사의 의미를 동시에 파악하 는 통합적인 능력이 요구된다(Crystal, 1966; Gallagher, 1970; Kiparsky, 1968). 시제 표지는 언어에 따라 다르게 표현되지만, 다양한 언어에서 동사의 문법형태소 어미 변화(morphological inflection) 에 의해 이루어진다. 따라서, 시제 관련 이해의 어려움은 동사 문법 형태소의 정확한 산출 및 이해의 어려움에 기인한다고 보고되고 있다(Berndt, Mitchum, Haendiges, \& Sandson, 1997; Kim \& Thompson, 2000, 2004; Luzzatti et al., 2002; Mätzig, Druks, Masterson, 
Jeein Kim, et al. • Aging and Tense Marker Processing from ERP Evidence

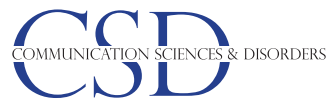

\& Vigliocco, 2009; Zingeser \& Berndt, 1990). 언어병리학 분야에서 실문법성 실어증(agrammatic aphasia) 환자들을 대상으로 시제 표 지의 이해 및 표현에 어려움이 관찰된다는 연구가 보고되고 있다 (Faroqi-Shah \& Thompson, 2007; Jo, Choi, \& Hwang, 2014; Kim, 2013; Lee, Kwon, Na, Bastiaanse, \& Thompson, 2013). Faroqi-Shah 와 Thompson (2007)에 따르면 일차적으로 시제 표지에 대한 이해 가 형태소 수준의 처리 과정을 거치기 때문에 문법성에 문제가 보 고되는 실문법성 실어증 환자들의 경우 이러한 시제 관련 형태소 처리에 어려움을 보이는 것으로 보고하였다.

한국어에서의 시제 표지의 경우, 크게 시제 부사와 동사의 어미 변형으로 이루어진다. 한국어의 경우, 동사 후치어(verb-final language)로서 동사 외에 다른 문장 성분의 이동이 비교적 자유롭다 (Sohn, 1999; Sung, 2015). 따라서, 시제 부사의 경우 문장의 처음에 위치하여 동사와 시제 부사간의 거리가 길어질 수도 있지만(예: '어 제 나는 동생과 함께 영화를 보았다'), 반면 시제 부사가 동사 가까 이에 위치할 경우에는 동사와 시제 부사와의 거리가 짧아질 수 있 다 (예: ‘나는 동생과 함께 영화를 어제 보았다' 또는 ‘나는 동생과 함께 어제 영화를 보았다'). 이와 같이 문장 수준에서 통사적 완결 성을 처리하는 과정에서 핵심 단어 간의 거리에 따라 인지적 자원 (cognitive resource)이 요구되는 정도가 달라질 수 있다. 영어권에 서는 문장의 통사적 완결성을 처리하는 과정에서 핵심 단어(head) 인 동사와 이에 선행하는 종속 성분들(dependents) 사이의 거리가 증가함에 따라 인지적 처리 자원(cognitive processing resources)이 더 많이 요구된다는 연구 결과가 보고되고 있다(Levy \& Keller, 2013). 이러한 효과를 설명하는 대표적인 이론 중 하나인 Dependency Locality Theory (Gibson, 2000)에 따르면 선행하는 종속 단 어들의 개수, 즉 거리(distance)에 따라 정보통합비용(integration cost)이 결정된다고 본다. 영어권 연구에서 구문 및 통사적 완결성 과 관련한 문장 성분 간 거리에 따라 요구되는 처리 용량(processing capacity)에서 차이가 있음을 밝히는 연구들이 다양하게 보고 되고 있다(Gibson, 2000; Gibson \& Warren, 1998; Konieczny, 2000; Levy \& Keller, 2013; Watkins, Gordon, \& Jeffries, 1998).

문장 성분 간 거리에 따른 처리 용량에 대한 연구는 대부분 자가 조절 읽기 패러다임(self-paced reading paradigm)을 사용하여 실 시간 문장 처리(real-time sentence processing) 과정을 측정하였다. 실시간 문장 처리를 살펴볼 수 있는 대표적인 방법 중 하나로 사건 관련전위(ERP) 연구 방법론이 있다. $\mathrm{ERP}$ 는 특정 언어 자극 이후에 밀리세컨드 단위로 뇌파 변화를 실시간으로 측정하는 것이 가능하 여 시간적 측면(temporal aspects)에서 강점이 있는 연구 방법으로 문장 처리 연구에서 다양하게 쓰이고 있다. 시제 표지 처리 과정과
관련하여서 또한 $\mathrm{ERP}$ 방법론을 적용한 연구가 아래와 같이 보고 되고 있다.

시제 표지 처리 과정과 관련된 ERP 연구 초기에는 주로 동사의 시제 활용과 관련된 형태론적 처리 과정(morphological processing)에 초점을 맞추어 이루어졌다(Allen, Badecker, \& Osterhout, 2003; Kutas \& Hillyard, 1983). 초기 연구에서 이와 같이 단어 중심 의 형태론적 처리 과정에 초점을 두었다면, 이후에는 시제 처리 과 정이 단순히 형태론적 처리 과정으로만 이루어지는 것은 아니라는 것을 전제로 시제 부사와 같은 다른 문장 성분 간의 관계 속에서 시 제 처리 과정을 연구하기 시작하였다. 즉, 시제를 처리하기 위해서 는 동사의 시제 관련 형태소 처리뿐만 아니라 문장 내에 시제를 나 타내는 시간 부사 등과 같은 시제 표지에도 영향을 받을 수 있다는 것을 확인하였다(Dillon, Nevins, Austin, \& Phillips, 2012; Fonteneau, Frauenfelder, \& Rizzi, 1998; Steinhauer \& Ullman, 2002).

Baggio (2008)의 연구에서는 시제 부사(구)와 동사의 시제를 일 치 또는 불일치시켜 시각적으로 문장들을 제시했을 때, 불일치 문 장에서 좌반구 전두 부적 파형(left anterior negativity, LAN) 및 $\mathrm{P} 600$ 성분이 확인되었다. LAN 성분은 형태통사론적 오류를 반영 하는 동시에 문장 처리 과정에서 요구되는 작업기억 용량(working memory capacity) 또는 인지적 처리 자원과 관련된 뇌파 성분으로 보고되고 있다(Angrilli et al., 2002; Barber \& Carreiras, 2005; Hagoort \& Brown, 2000; Kluender \& Kutas, 1993; Leinonen, Brattico, Järvenpää, \& Krause, 2008; Osterhout \& Mobley, 1995; Roehm, Bornkessel, Haider, \& Schlesewsky, 2005; Streb, Rösler, \& Hennighausen, 1999). LAN 성분 중에서도 100-200 ms 구간에서 나타나 는 초기 반응을 early left anterior negativity (ELAN)로 명명하기 도 하였다(Friederici, 2002). P600 성분은 전통적으로는 문법 오류 와 관련된 뇌파 성분으로 알려져 왔지만(Luck, 2014), 이 외에도 문 맥상의 의미적 표상을 지닌 어휘 정보를 통합시키고, 문장을 재분 석 및 수정하는 것과 관련된 뇌파로 보고되기도 하였다(Featherston, Gross, Münte, \& Clahsen, 2000; Gouvea, 2003; Kaan, Harris, Gibson, \& Holcomb, 2000).

문장 성분 간 거리에 따른 처리 용량의 차이에 대한 ERP 연구들 은 주로 주어-동사-목적어의 기본 어순을 지니는 영어권 국가들에 서 활발하게 이루어져 왔다. 특히, 영어권에서는 문장 성분 간 거리 에 따른 언어 처리 과정을 wh-의존성(wh-dependency) 또는 대명 사에 대한 담화 표지를 중심으로 연구가 진행되어 왔다. 즉, 문장 또 는 담화 수준의 통사적 완결성을 처리하는 과정에서 핵심 단어와 의존어 사이의 거리가 증가함에 따라 요구되는 처리 용량 또한 증 가하며, 이는 작업기억 용량과 밀접한 관련이 있음이 보고되었다 
(Watkins et al., 1998; Konieczny, 2000; Levy \& Keller, 2013). Phillips, Kazanina와 Abada (2005)의 연구에서는 의문사 의존관계 (wh-dependency)를 반영하는 동사에서 구문을 통합하기 위한 처 리 과정 용량(processing cost)을 반영하는 것으로 P600 반응을 확 인하였다.

문장 성분 간 거리에 따른 ERP 연구는 영어권 정상 청년층 연구 에 국한되어 있다. 따라서, 이러한 연구결과가 동사 후치어라는 문 법적 특징을 가진 한국어 사용자에게 직접적으로 적용 가능한 근 거인지 검증이 필요하다. 본 연구에서는 시제 표지와 관련된 문장 성분 간 거리를 조정하였을 때, 동사 후치어를 사용하는 한국어 화 자에게 나타나는 ERP 성분이 청년층과 노년층 간 어떠한 차이가 있는지를 살펴보고자 하였다. 노년층을 대상으로 한 시제 표지 관 련 ERP 연구는 영어권 사용자에서도 연구가 매우 제한적이다. 노 화가 진행됨에 따라 문장 처리 능력의 저하를 보고하는 연구들은 다양하게 보고되어 왔으나, 대부분의 연구는 오프라인 측정(offline measure, end-of-sentence measure)에 의존하거나 자가조절 읽기 또는 듣기 패러다임을 쓴 연구이며(Caplan, DeDe, Waters, Michaud, \& Tripodis, 2011; Caplan \& Waters, 2005; Kemtes \& Kemper, 1997), $\mathrm{ERP}$ 를 사용한 실시간 문장 처리에 대한 연구는 찾아보기 힘들다. 일반적으로 노년층의 경우, 단어 이해나 사실적 의미에 대한 이해 는 청년층과 크게 차이가 나지 않는 것으로 보고되었다(Bayles, Tomoeda, Kaszniak, Stern, \& Eagans, 1985; Belmore, 1981; Cohen, 1979). 하지만 얼굴과 이름을 연결하거나, 시간과 장소를 연결하는 등 맥락 간 연합 과정을 요구하는 문장 처리 과정에서는 감퇴가 두 드러지는 것으로 나타났다(Balota, Dolan, \& Duchek, 2000). 이처 럼 노화에 따라 감퇴되는 언어 능력의 양상은 다양한 수준의 정보 처리 과정을 포함하며, 복잡한 인지기능들과 연결되어 있다고 볼 수 있다. 이러한 측면에서, 시제 표지 간의 거리 조절에 따라 요구되 는 처리 용량이 한국어 문장 처리에서 청년층과 노년층 간에 어떠 한 차이가 나타나는지 살펴보는 것은 노화와 관련된 언어 처리 손 상과 관련된 또 다른 언어적 지표를 확인할 수 있다는 점에서 의미 가 있다.

본 연구에서는 문장 성분 간 거리에 따른 시제 표지 일치 여부를 판단하는 과제에서 청년층과 노년층 두 집단 간 문장판단과제에서 의 반응 및 ERP 평균진폭(mean amplitude)에서의 차이가 유의한 지 알아보고자 한다. 본 연구의 구체적인 연구 질문과 가설은 다음 과 같다.

첫째, 시제 표지 간 거리(원거리 vs. 근거리)에 따라 시제 표지 일 치 여부를 판단하는 문장판단과제의 정반응률 및 반응시간에서 청년층과 노년층 간 차이가 유의한가? 본 연구 질문에 대한 가설 및
이론적 배경에 근거한 예측 결과는 인지적 용량이 저하되어 있는 노년층의 경우, 시제 표지 간 거리가 멀어질 때(즉, 원거리 조건)에서 청년층에 비해 더 큰 어려움을 겪게 될 것으로 예상하며, 이는 원거 리 조건에서 낮은 정반응률과 긴 반응시간이 관찰되는지를 집중적 으로 살펴보고자 한다.

둘째, 시제 표지 간 거리(원거리 vs. 근거리)에 따라 시제 표지 일 치 여부를 판단하는 문장판단과제의 ERP의 평균진폭(mean amplitude)에서 청년층과 노년층 간 차이가 유의한가? 본 연구 질문에 대한 가설은 인지적 용량이 더 많이 요구되는 원거리 조건에서 근 거리 조건에 비해 노년층에서 인지적 용량에 따른 ERP 요소들이 청년층과는 다른 패턴이 나타나는지를 검증하는 것이다.

\section{연구방법}

\section{연구대상}

본 연구는 정상 청년층 15 명과 정상 노년 집단 17 명, 총 32 명을 대 상으로 진행하였다. 청년층은 만 20-39세, 노년층은 만 60-69세로 집단을 구성하였으며, 노년층의 연령 기준은 우리나라 법률상 노인 및 고령자 연령 기준에 따라 정하였다. 고령자고용촉진법, 노인복지 법, 국민기초생활보장법상에서 규정하고 있는 연령의 평균을 구하 여 노년층의 연령 기준을 60 세 이상으로 선정하였다.

모든 대상자는 (1) 모국어가 한국어, (2) 교육년수가 6년 이상으 로 청년층과 노년층 간 교육년수에서 유의한 차이가 없도록 일치시 켰으며 $\left(F_{(1,28)}=2.535, p=.123\right)$, (3) 서울 및 경기 지역에 거주하는 자, (4) 오른손잡이 및 교정시력을 포함한 시력이 정상이며, (5) 한국 판 간이정신상태검사(Korean-Mini Mental State Examination KMMSE; Kang, Na, \& Hahn, 1997)에서 16\%ile 이상으로 정상 범위 에 속해야 한다. 정상 노년층 집단은 추가적으로 (1) SVLT (Seoul Verbal Learning Test; Kang \& Na, 2003)에서 16\%ile 이상, (2) Forward and Backward Digit Span (Yeom, Park, Oh, Kim, \& Lee, 1992) 을 실시하여 규준에 따라 정상 범주에 속하는 자로 선정하였다.

총 32 명의 대상자 중 문장판단과제에서 정반응률이 $60 \%$ 이하인

Table 1. Descriptive information on participants

\begin{tabular}{lccc}
\hline & Young group & Elderly group & Total \\
\hline Gender & & & \\
Male & 3 & 5 & 8 \\
Female & 12 & 12 & 24 \\
Age (yr) & $28 \pm 5(21-37)$ & $62 \pm 3(60-69)$ & $46 \pm 18(21-69)$ \\
Education (yr) & $15 \pm 1(12-16)$ & $13 \pm 2(9-18)$ & $14 \pm 2(9-18)$ \\
\hline
\end{tabular}

Values are presented as average \pm SD (range). 
노년층 대상자 2 명은 데이터 분석에서 제외하였다. 본 연구에 참여 한 연령 집단별 대상자 정보는 Table 1에 제시하였다.

\section{실험과제}

\section{실험 자극}

실험에 사용된 문장은 Sung과 Kwag (2012)을 참고로 하여 3항 동사를 선택하여 구성하였다. 3 항 동사의 특성에 따라, 문장 성분 은 주격, 목적격, 여격, 동사를 기본 구조로 하여, 시제 부사를 첨가 하여 총 5 어절로 이루어진 문장으로 선정하였다. 이렇게 5 어절로 구성된 문장에서 시제 부사와 동사간 거리를 두 가지로 조절하였다. 하나는 시제 부사와 동사 간 거리가 짧은 조건(예: 주격+여격+목적 격+시제 부사+동사)이며, 다른 하나는 시제 부사와 동사 간 거리가 긴 조건(예: 시제 부사+주격+여격+목적격+동사)으로 구성하였다.

시간 부사가 주어 앞에 제시되는 경우 시간 부사와 동사 사이의 거리는 14 음절로 통제하였다. 문장에 사용된 단어들 중 동사는 5어 절의 문장 길이와 문장 구조를 일치시키기 위하여 Sung과 Kwag (2012)을 참고로 하여 3항 동사로 선정하였다. 또한 문장에 사용된 어휘들은 Nam과 Hong (2013)을 참고로 하여 선정하였고, 사용된 어휘들 중 명사는 보통 명사로 통일하였다. 주어는 '남자' 또는 '여 자'로 일치시켰으며, 주격조사의 경우 '-이/-가’로 통일하였다. 시간 부사는 고등학교 문법(교육부, 1997) 및 Woo (1991)의 논문에 제시 된 시간 부사들 중 용언의 과거형 또는 미래형과 공기하는 것들 중 보다 명확한 시제상을 제시하는 것이라 평가되는 부사들 중에서 선정하였다.

문장의 시제는 과거와 미래시제를 사용하였다. 현재형 동사의 경 우 평소의 습관, 상태, 불변의 법칙 등을 포괄하여 쓰이는 표현이며, 현재 시간 부사는 용언의 과거형 및 미래형과도 공기할 수 있기 때 문에 제외하였다. 동사의 과거형은 선어말 어미 '-았-/-었'으로, 미 래형은 선어말 어미 '-(으)ㄹㅇㅔ 의존명사 '것'이 합쳐진 '-(으)ㄹ 것' 으로 정하였다. 동사의 미래형 중 선어말 어미 '-겠'의 경우 추측,
의지, 가능성 등의 양태적 의미가 강하고, 이러한 형태의 미래시제 가 평서문에서 사용될 경우 1 인칭에서만 쓰일 수 있다는 점 때문에 제외하였다. 반면에, 관형사형 선어말 어미 '-(으)르 것'으로 표현되 는 미래시제의 경우 양태적 의미가 희박하고 단순한 미래를 나타내 기 때문에 더 명백한 시제상을 표현할수 있다.

Table 2에 제시한 바와 같이, 각 조건별로 15 개 문항으로 구성되 며, 일치성 여부에 따라 30 문항, 거리 조건에 따른 문항 30 문항으로 이루어져 총 60 문항의 실험문장으로 구성하였다. 문장 불일치 조 건은 크게 (1) 과거부사+미래시제 동사, 또는 (2) 미래부사+과거시 제 동사로 구성되며, 하나의 동사는 불일치 문장에서 2 가지 조건과 일치 문장에서 2 가지 조건, 총 4 가지 조건에 한 번씩 출현하여 4 회 씩 반복되었다.

문장 내에서 오류가 발생하는 위치는 모두 문장의 마지막 단어 인 동사로 해당 동사가 ‘실험 단어'로 기능한다. 해당 단어가 제시되 기 $200 \mathrm{~ms}$ 전부터 제시되고 난 후 $900 \mathrm{~ms}$ 까지를 분석 대상으로 삼 았다. 시간 부사의 위치 및 부사와 동사의 시제 일치 여부에 따라 4 가지 유형의 문장으로 구성하였으며, 실험 문장은 총 60 개, 메꿈질 문장(filler sentences)은 30 개로 총 90 문장으로 실험을 구성하였다. 메꿈질 문장 또한 정상 문장과 오류 문장의 비율을 동일하게 맞추 었으며, 시제상을 제시하지 않는 문장들로 제작하였다. 본 연구의 실험 자극의 예를 Table 2에 제시하였다. 한국어의 영어표기는 Yale Romanization System (Martin, 1992)을 사용하였다. 실험 자극 문 장은 Appendix 1에 제시하였다.

\section{문장판단과제}

실험 자극은 총 60 개의 목표 문장과 30 개의 메꿈질 문장을 유사 무작위 배열(pseudo-randomization)로 구성하였다. 동일한 문항 을 3 개의 리스트로 제작하여 피험자별로 돌아가면서 사용하였다. 하나의 실험은 총 3 개의 세트로 구성되었으며, 각 세트 사이에 1 분 씩의 쉬는 시간이 주어졌다. 피험자의 과제 수행 방식의 이해를 돕

Table 2. Examples of sentence stimuli for each condition

\begin{tabular}{|c|c|c|c|c|c|c|}
\hline \multirow{2}{*}{$\begin{array}{l}\text { Tense agreement } \\
\text { Agree }\end{array}$} & \multirow{2}{*}{$\begin{array}{c}\text { Distance } \\
\text { Long }\end{array}$} & \multicolumn{5}{|c|}{ Examples of sentence stimuli } \\
\hline & & ecey & yeca-ka & pyek-ey & cepsi-lul & tenci-ett-ta. \\
\hline & Short & Yesterday & woman-Nom. & wall-Loc. & dish-Acc. & threw-past.dec. \\
\hline & & Yeca-ka & pyek-ey & cepsi-lul & ecey & tenci-ett-ta. \\
\hline & & Woman-Nom. & wall-Loc. & dish-Acc. & yesterday & threw-past.dec. \\
\hline \multirow[t]{4}{*}{ Disagree } & Long & ecey & yeca-ka & pyek-ey & cepsi-lul & tenci-I-kes-ita. \\
\hline & & Yesterday & woman-Nom. & wall-Loc. & dish-Acc. & will throw-fut.dec. \\
\hline & Short & Yeca-ka & pyek-ey & cepsi-lul & ecey & tenci-I-kes-ita. \\
\hline & & Woman-Nom. & wall-Loc. & dish-Acc. & yesterday & will throw-fut.dec. \\
\hline
\end{tabular}

The bold and italicized words are critical words. 
기 위해 총 5 개의 연습 문항을 제시하였다. 연습 문항에 대해서는 피험자의 반응에 대해 피드백이 제공되었다.

본 실험이 시작되면 화면 가운데에 ‘+' 표시가 나타난 뒤 5어절 문장이 1어절씩 주어진다. '+ 표시가 나타나는 시간은 $500 \mathrm{~ms}$ 이며, 1 어절씩 제시되는 시간은 $700 \mathrm{~ms}$ 로 정하였다. 어절이 제시되는 화 면과 시선이 고정되는 화면의 사이는 $200 \mathrm{~ms}$ 의 interstimulus interval (ISI)로 빈 화면을 제시하였다. 마지막으로 앞에 제시된 문장을 4 어절로 간략하게 화면에 제시된다. 이때 피험자는 문장의 내용이 문법적으로 옳은 문장인지를 판단하여 옳은 문장이라고 생각하 면 키보드 오른쪽에 파란색으로 표시된 버튼을 누르고, 옳지 않은 문장이라고 생각하면 키보드 왼쪽에 빨간색으로 표시된 버튼을 눌러 오류 여부를 판단하게 된다. 또한, 전체 문장이 제시되면 가능 한 한 빠르고 정확하게 키보드의 지정된 버튼을 누르도록 하였다. 피험자는 1 어절씩 문장이 모두 제시되는 동안에는 반응을 하지 않 도록 하였으며, 문장이 모두 제시된 후 4 어절로 제시되는 전체 문장 은 4,000 ms 동안 제시하였으며, 문장의 오류 여부를 판단하는 동 시에 화면에서 전체 문장은 사라지도록 하였다. 만약 최대로 주어 진 $4,000 \mathrm{~ms}$ 가 지나도록 피험자가 반응이 없더라도 눈을 깜박이며 다음 문항을 준비할 수 있도록 $3,000 \mathrm{~ms}$ 의 시간을 추가적으로 두었 다. 실험의 총 소요시간은 1 분씩 2 회의 쉬는 시간을 포함하여 약 20 분이며, 문장판단과제의 자극 제시 순서는 Figure 1 과 같다.

\section{ERP 실험}

본 실험은 실험 자극 이외의 외부 요인에 의해 유발된 전파를 차 단하도록 실드룸(shield room) 안에서 Brain Products사의 BrainAmp Standard와 actiCAP을 사용하여 EEG를 기록하였다. 피험자 의 두피에 은/염화은 전극을 국제 표준방식인 10-20 System (Jasper,
1958)에 따라 Fp1, Fp2, F7, F3, Fz, F4, F8, FC5, FC1, FC2, FC6, T7, C3, C2, C4, T8, TP9, CP5, CP1, CP2, CP6, TP10, P7, P3, Pz, P4, P8, $\mathrm{O} 1, \mathrm{O} 2$, 총 29 개의 전극을 부착하였다. 오른쪽 눈 밑에 전극을 부착 하여 눈 깜박임을 탐지하도록 안전도(electrooculogram, EOG)를 측정하였고, 피험자의 양쪽 유양돌기에 2 개의 기준전극(reference electrodes)을 부착하였다. 뇌파 신호는 $500 \mathrm{~Hz}$ 로 샘플링되었고, 전 극 저항은 $10 \mathrm{k} \Omega$ 이하로 맞추었다. 모니터와 앉아있는 피험자의 거 리는 $1 \mathrm{~m}$ 로 정하였고, 문장이 제시되는 동안 눈 및 신체의 움직임 에 대한 주의 사항을 전달하였다. 실험 시 실드룸(shield room) 안 의 불빛은 모두 소등되었으며, 모니터만 켜진 상태에서 피험자는 과 제를 수행하였다. 실험이 진행되는 모든 과제 수행은 EEG로 기록 되었으며, 문장의 마지막 단어(동사)가 주요 분석 단어(critical word)이다. 분석에 포함된 전극은 midline $(\mathrm{Fz}, \mathrm{Cz}, \mathrm{Pz})$, left anterior (FP1, F3, FC5, FC1, F7), left posterior (CP5, CP1, P7, P3, O1), right anterior (FP2, F4, FC2, FC6, F8), right posterior (CP2, CP6, P4, P8, $\mathrm{O} 2)$ 이다.

\section{연구절차 및 자료분석}

문장판단과제의 정반응률은 피험자가 판단한 문장의 오류 여부 와 실제 오류 유무를 대조하여 분석하였다. 정반응한 목표 문장수 를 전체 목표 문장수로 나누어 백분율(\%)로 산출하였다. 정반응률 이 $60 \%$ 미만인 대상자의 경우 데이터 분석에서 제외하였다.

반응시간은 밀리세컨드 $(\mathrm{ms})$ 단위로 측정하였으며, 화면에 전체 문장이 제시된 순간부터 피험자가 문장의 오류 여부를 판단하여 버튼을 누른 시간까지를 측정하였다. E-Prime을 통해 측정되었고, 반응시간은 피험자가 정반응한 문항들에 대해서만 분석되었다.

실험을 통해 얻은 $\mathrm{EEG}$ 데이터 중 피험자들이 정반응한 문항들을

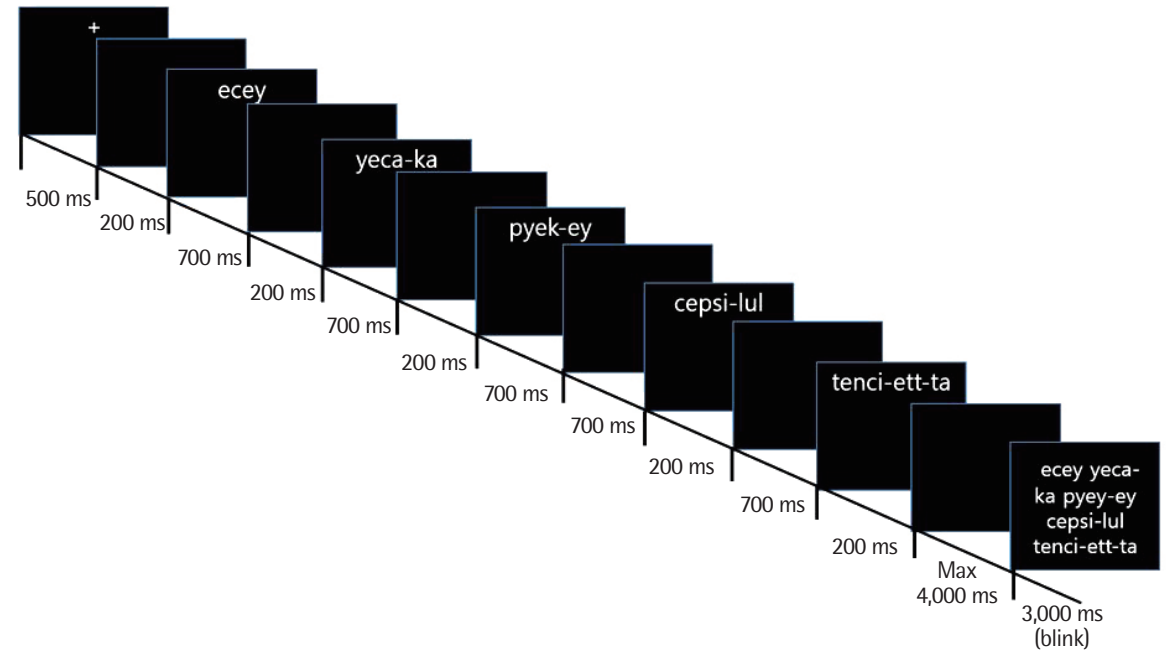

Figure 1. Paradigm for visual presentation. 
대상으로 분석하였다. 분석을 위해 MATLAB R2013b와 EEGLAB $\mathrm{v} 12.0 .2 .5 \mathrm{~b}$ 프로그램을 사용하였다. 정반응한 문항들을 대상으로 $250 \mathrm{~Hz}$ 에 맞추어 다시 샘플링하였으며, 한 단어 분석과 연속단어 분석이 수행되었다.

한 단어 분석의 경우 실험 단어가 제시되기 전 $300 \mathrm{~ms}$ 부터 실험 단어 제시 후 $900 \mathrm{~ms}$ 까지 총 $1,100 \mathrm{~ms}$ 간격으로 구성하여 분석하 였다. 인지작용에 대한 뇌파를 추출하기 위해.1-30 Hz 범위에서 필 터링하였고, 눈 깜박임으로 인한 잡음을 제거하기 위해 안구 교정 뒤 이에 해당하는 시행들을 제거하였다. 이러한 과정을 통해 추출 된 시행들을 평균하여 각 집단의 평균 $\mathrm{ERP}$ 파형을 구하였다.

본 연구의 첫 번째 질문인 정상 청년과 정상 노년 집단 간 시제 표 지 판단 과제에서 부사 위치에 따른 정반응률 및 반응시간의 차이 가 유의한지 알아보기 위하여 삼원혼합분산분석(three-way mixed ANOVA)을 실시하였다. 두 번째 연구 문제인 두 집단(노년층, 청년 층) 간 문장 내 부사 위치에 따라 $\mathrm{ERP}$ 의 평균진폭 및 정점출현시각 의 차이가 유의한지를 알아보기 위해 five-way mixed ANOVA를 실시하였다. 통계적 분석은 SPSS version 20 (IBM, Armonk, NY, USA)을 사용하였다.

Table 3. Descriptive statistics of accuracy (\%) on the sentence plausibility judgment task as a function of distance and tense agreement for each group

\begin{tabular}{lccc}
\hline $\begin{array}{l}\text { Tense reference } \\
\text { agreement }\end{array}$ & $\begin{array}{c}\text { Tense reference } \\
\text { distance }\end{array}$ & $\begin{array}{c}\text { Young } \\
(\mathrm{N}=15)\end{array}$ & $\begin{array}{c}\text { Elderly } \\
(\mathrm{N}=15)\end{array}$ \\
\hline Agree & Short & $96.44(4.96)$ & $84.00(18.48)$ \\
\multirow{2}{*}{ Disagree } & Long & $91.56(7.33)$ & $78.67(18.72)$ \\
& Short & $96.89(4.96)$ & $94.22(7.50)$ \\
& Long & $98.22(3.05)$ & $88.00(13.85)$ \\
\hline
\end{tabular}

Values are presented as mean \pm SD.

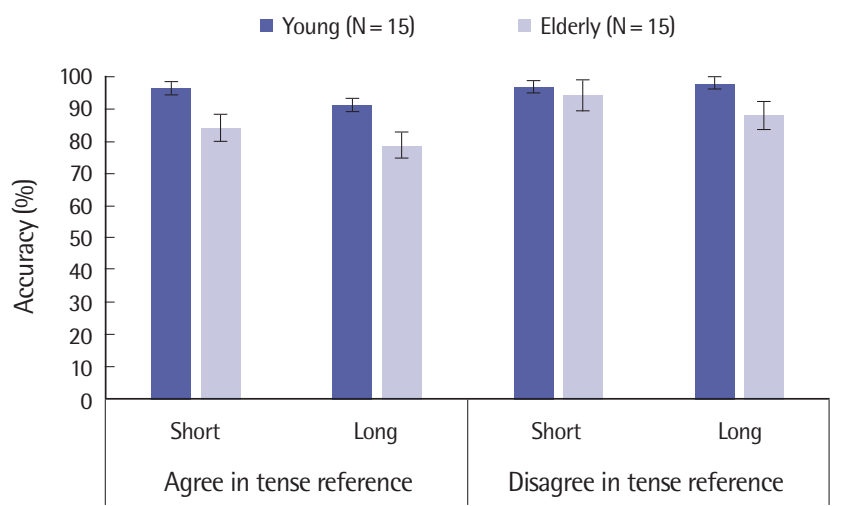

Figure 2. Accuracy on the sentence plausibility judgment task as a function of distance and tense agreement for each group (error bar based on standard error).

\section{연구결과}

\section{정반응률}

시제 표지 간 거리에 따른 시제 표지 일치 여부 판단과제의 집단 간 정반응률의 차이를 알아보기 위하여 집단(청년, 노년), 시제 표 지 일치 여부(일치, 불일치), 시제 표지 간 거리(원거리, 근거리)를 독 립 변인, 시제 표지 일치 여부를 판단하는 문장판단과제의 정반응 률을 종속 변인으로 하는 삼원혼합분산분석(three-way mixed ANOVA)을 실시하였다. 시제 표지 일치 여부 및 시제 표지 간 거리 에 따른 집단별 정반응률의 표준 편차는 Table 3과 Figure 2에 제시 하였다.

시제 표지 간 거리 및 시제 표지 일치 여부에 따른 시제 표지 처리 과정에 대한 문장판단과제의 정반응률에서 집단에 대한 주효과가 통계적으로 유의하였다 $\left(F_{(1,28)}=11.454, p<.01\right)$. 즉, 청년층의 정반응 률이 노년층의 정반응률에 비해 유의하게 높았다. 시제 표지 간 거리 에 대한 주효과도 통계적으로 유의하였다 $\left(F_{(1,28)}=13.715, p<.001\right)$. 즉, 시제 표지 간 근거리에서의 정반응률이 시제 표지 간 원거리에 서의 평균 정반응률에 비해 유의하게 높았다. 또한 시제 표지 일치 여부에 대한 주효과도 통계적으로 유의하였다 $\left(F_{(1,28)}=6.294, p<.05\right)$. 즉, 시제 표지 불일치 유형에서의 정반응률이 시제 표지 일치 유형 에서의 정반응률에 비해 유의하게 높았다. 그 외 상호작용은 유의 하지 않은 것으로 나타났다. 시제 표지 일치 여부 및 시제 표지 간 거리에 따른 집단 간 문장판단과제의 정반응률에 대한 분산분석 결과는 Table 4에 제시하였다.

Table 4. ANOVA results from the accuracy (\%) on the sentence plausibility judgment task

\begin{tabular}{|c|c|c|c|c|}
\hline Distributed source & $\begin{array}{l}\text { Sum of } \\
\text { squares }\end{array}$ & $d f$ & $\begin{array}{l}\text { Mean } \\
\text { square }\end{array}$ & $F$ \\
\hline \multicolumn{5}{|l|}{ Between factor } \\
\hline Group & 61.633 & 1 & 61.633 & $11.454^{* *}$ \\
\hline Error & 150.667 & 28 & 5.381 & \\
\hline \multicolumn{5}{|l|}{ Within factor } \\
\hline Distance & 9.633 & 1 & 9.633 & $13.715^{* * *}$ \\
\hline Distance $\times$ Group & 2.700 & 1 & 2.700 & 3.844 \\
\hline Error & 19.667 & 28 & .702 & \\
\hline Agreement & 30.000 & 1 & 30.000 & $6.294^{*}$ \\
\hline Agreement×Group & 6.533 & 1 & 6.533 & 1.371 \\
\hline Error & 133.467 & 28 & 4.767 & \\
\hline Distance ×Agreement & 1.200 & 1 & 1.200 & 1.214 \\
\hline Distance $\times$ Agreement $\times$ Group & 2.133 & 1 & 2.133 & 2.159 \\
\hline Error & 27.667 & 28 & .988 & \\
\hline
\end{tabular}

${ }^{*} p<.05,{ }^{* *} p<.01,{ }^{* * *} p<.001$. 


\section{반응시간}

시제 표지 간 거리에 따른 시제 표지 일치 여부 판단과제의 집단 간 반응시간의 차이를 알아보기 위하여 집단(청년, 노년), 시제 표 지 일치 여부(일치, 불일치), 시제 표지 간 거리(원거리, 근거리)를 독 립 변인, 시제 표지 일치 여부 판단과제의 반응시간을 종속 변인으 로 하는 삼원혼합분산분석(three-way mixed ANOVA)을 실시하 였다. 시제 표지 일치 여부 및 시제 표지 간 거리에 따른 집단별 반 응시간의 표준편차는 Table 5 와 Figure 3 에 제시하였다.

시제 표지 간 거리 및 시제 표지 일치 여부에 따른 시제 표지 처리 과정에 대한 문장판단과제의 반응시간에서 집단에 대한 주효과가 통계적으로 유의하였다 $\left(F_{(1,28)}=32.018, p<.001\right)$. 즉 청년층의 평균 반응시간이 노년층의 평균 반응시간에 비해 유의하게 빨랐다. 시제 표지 간 거리에 대한 주효과도 통계적으로 유의하였다 $\left(F_{(1,28)}=7.559\right.$, $p<.01)$. 즉, 시제 표지 간 근거리에서의 평균 반응시간이 시제 표지 간 원거리에서의 평균 반응시간에 비해 유의하게 빨랐다. 시제 표 지 일치 여부에 대한주효과는 통계적으로 유의하지 않았다.

집단과 시제 표지 간 거리, 시제 표지 간 일치 여부 및 집단 간의

Table 5. Descriptive statistics of reaction time (ms) on the sentence plausibility judgment task as a function of distance and tense agreement for each group

\begin{tabular}{lccc}
\hline $\begin{array}{l}\text { Tense reference } \\
\text { agreement }\end{array}$ & $\begin{array}{c}\text { Tense reference } \\
\text { distance }\end{array}$ & $\begin{array}{c}\text { Young } \\
(\mathrm{N}=15)\end{array}$ & $\begin{array}{c}\text { Elderly } \\
(\mathrm{N}=15)\end{array}$ \\
\hline Agree & Short & $611.95(373.84)$ & $1,622.68(612.99)$ \\
& Long & $724.02(443.60)$ & $1,619.61(554.73)$ \\
Disagree & Short & $549.03(282.15)$ & $1,515.60(592.36)$ \\
& Long & $596.73(288.95)$ & $1,683.66(744.49)$ \\
\hline
\end{tabular}

Values are presented as mean $\pm S D$.
삼차상호작용이 통계적으로 유의하였으나 $\left(F_{(1,28)}=6.680, p<.05\right)$, 그 외 상호작용은 유의하지 않았다. 시제 표지 일치 여부 및 시제 표 지 간 거리에 따른 집단 간 문장판단과제의 반응시간에 대한 분산 분석 결과는 Table 6에 제시하였다.

\section{평균진폭(mean amplitude) 크기 분석}

청년층과 노년층의 전극 위치별 시제 표지 일치 여부 및 거리에 따른 평균 파형(grand average wave forms) 결과는 Figure 4 (청년 층) 및 Figure 5 (노년층)에 제시하였다. 집단(young vs. old) $\times$ 거리 (short vs. long) $\times$ 시제 표지 일치 여부(agree vs. disagree) $\times$ 좌우영 역(left vs. right) $\times$ 전후(anterior vs. posterior)에 대한 five-way ANOVA 결과는 구간별로 Table 7에 제시하였다. 또한, Table 7에 나타난 유의한 주효과 및 상호작용은 분석 구간별로 나누어 기술

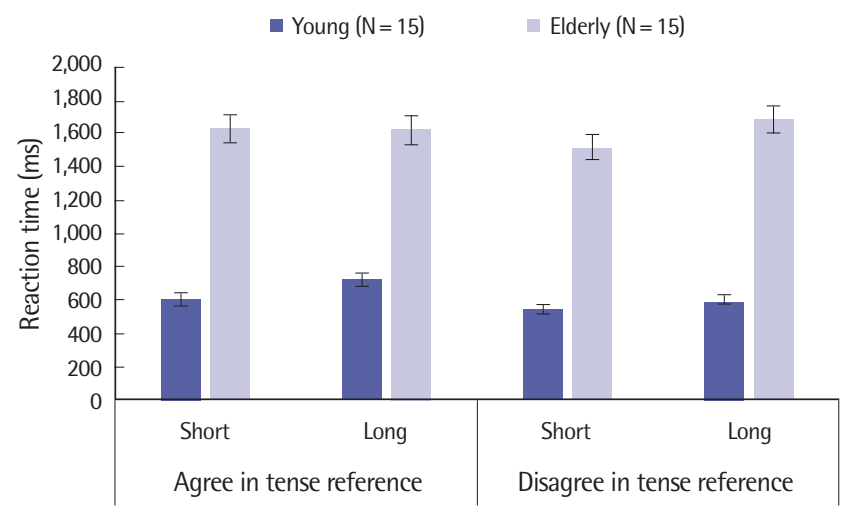

Figure 3. Reaction time on the sentence plausibility judgment task as a function of distance and tense agreement for each group (error bar based on standard error).

Table 6. ANOVA results from the reaction time (ms) on the sentence plausibility judgment task

\begin{tabular}{|c|c|c|c|c|}
\hline Distributed source & Sum of squares & $d f$ & Mean square & $F$ \\
\hline \multicolumn{5}{|l|}{ Between factor } \\
\hline Group & $29,400,261.19$ & 1 & $29,400,261.19$ & $32.018^{* * *}$ \\
\hline Error & $25,711,030.59$ & 28 & $918,251.093$ & \\
\hline \multicolumn{5}{|l|}{ Within factor } \\
\hline Distance & $197,754.836$ & 1 & $197,754.83$ & $7.559^{* *}$ \\
\hline Distance $\times$ Group & 50.977 & 1 & 50.977 & .002 \\
\hline Error & $732,567.693$ & 28 & $26,163.132$ & \\
\hline Agreement & 10,199.337 & 1 & $10,199.337$ & 1.212 \\
\hline Agreement×Group & $40,616.196$ & 1 & $40,616.196$ & .483 \\
\hline Error & 2,356,499.694 & 28 & $84,160.703$ & \\
\hline Distance $\times$ Agreement & $21,371.809$ & 1 & $21,371.809$ & 1.373 \\
\hline Distance $\times$ Agreement $\times$ Group & $103,978.421$ & 1 & $103,978.421$ & $6.680^{*}$ \\
\hline Error & $435,819.640$ & 28 & $15,564.987$ & \\
\hline
\end{tabular}

${ }^{*} p<.05,{ }^{* *} p<.01,{ }^{* * *} p<.001$. 


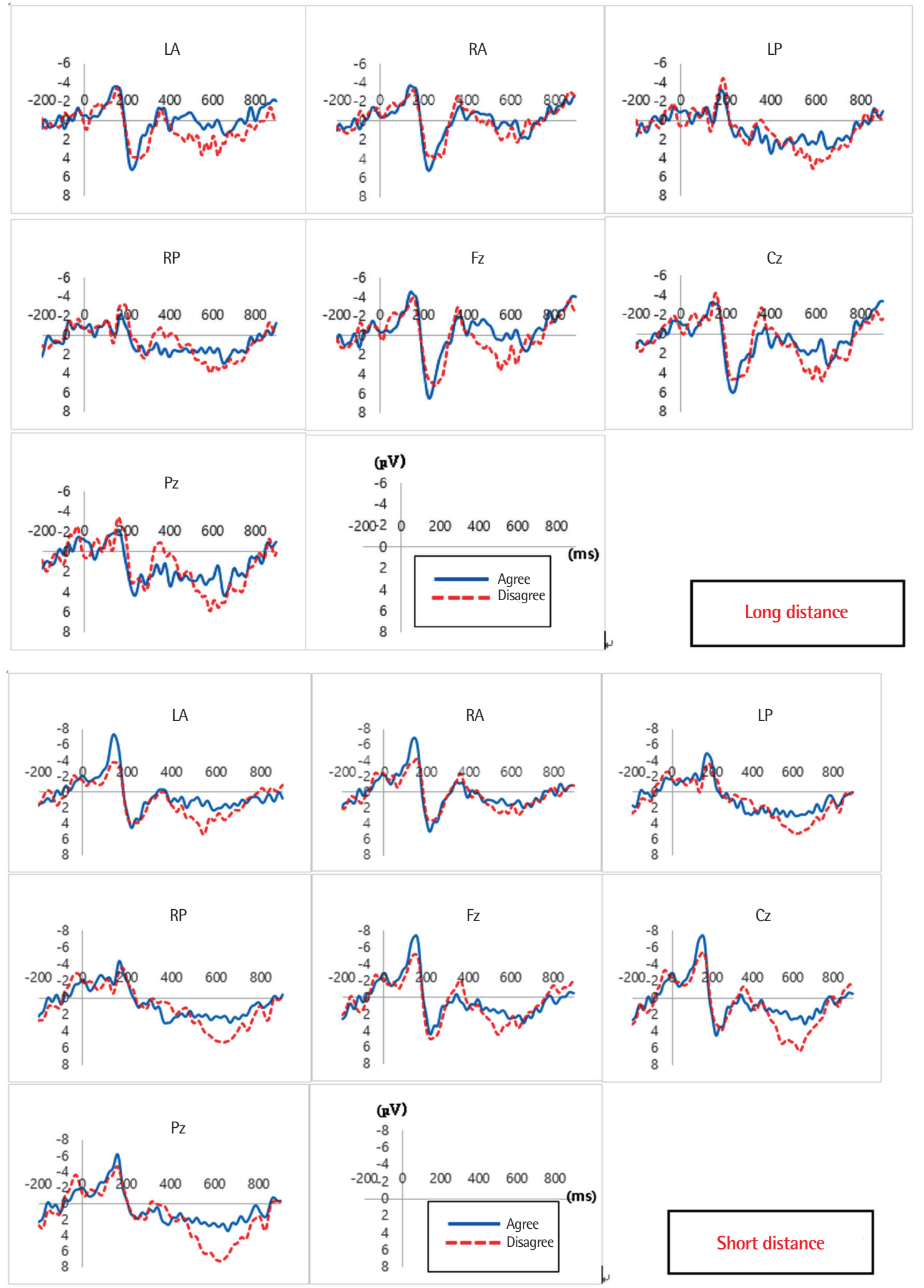

Figure 4. Grand-average waveforms as a function of tense agreement and distance for young adults. $L A=$ left anterior; $R A=$ right anterior; $L P=$ left posterior; $R P=$ right posterior. 

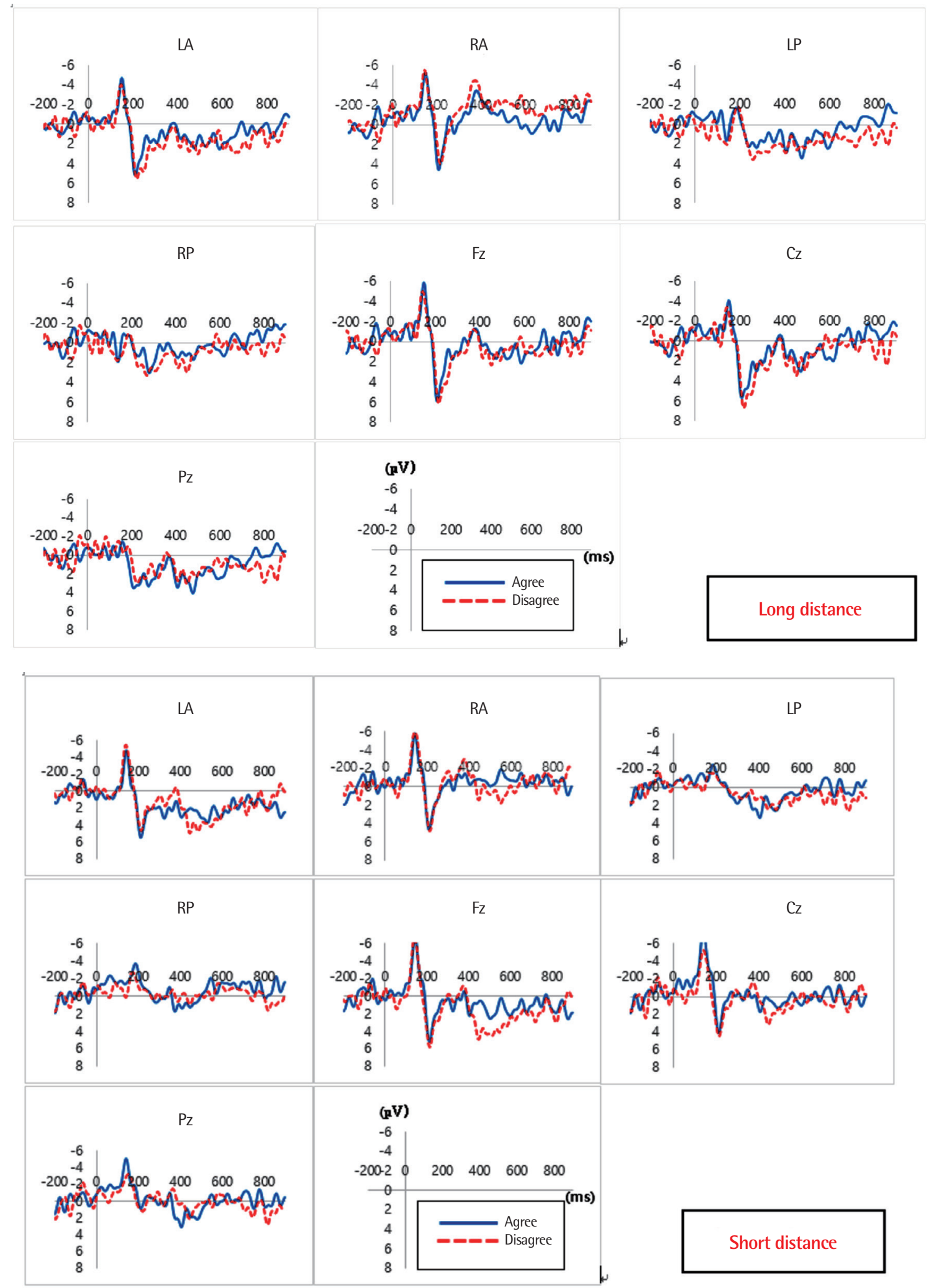

Figure 5. Grand-average waveforms as a function of tense agreement and distance for elderly adults. $L A=$ left anterior; $R A=$ right anterior; $L P=$ left posterior; $R P=$ right posterior. 
Table 7. Five-way ANOVA results for mean amplitude in each time window

\begin{tabular}{|c|c|c|c|}
\hline \multirow{2}{*}{ Effects } & \multicolumn{3}{|c|}{$F$-value } \\
\hline & $100-200 \mathrm{~ms}$ & $300-500 \mathrm{~ms}$ & $600-800 \mathrm{~ms}$ \\
\hline$G$ & 1.871 & .000 & $8.058^{* *}$ \\
\hline D & $.7 .270^{*}$ & 1.262 & .664 \\
\hline$D \times G$ & .060 & .003 & .040 \\
\hline A & .597 & .000 & 1.696 \\
\hline$A \times G$ & .113 & .141 & .015 \\
\hline L & 1.724 & $19.980^{* * *}$ & $18.760 * * *$ \\
\hline$L \times G$ & 3.260 & 1.985 & 1.623 \\
\hline Ant & $7.248^{*}$ & $6.290^{*}$ & 1.471 \\
\hline Ant $\times G$ & 1.094 & .337 & 3.185 \\
\hline$D \times A$ & .461 & .000 & .723 \\
\hline$D \times A \times G$ & .199 & .020 & .002 \\
\hline$D \times L$ & 1.760 & $11.813^{* *}$ & 2.933 \\
\hline$D \times L \times G$ & .935 & .001 & 1.641 \\
\hline$A \times L$ & 1.785 & .696 & 1.465 \\
\hline$A \times L \times G$ & 3.008 & .066 & .897 \\
\hline$D \times A \times L$ & .131 & .012 & $7.44^{*}$ \\
\hline$D \times A \times L \times G$ & 1.179 & .000 & 3.577 \\
\hline$D \times$ Ant & .012 & 1.178 & 3.921 \\
\hline$D \times A n t \times G$ & 3.305 & 2.713 & .644 \\
\hline$A \times$ Ant & $6.467^{*}$ & 4.795 & .539 \\
\hline$A \times A n t \times G$ & $5.938^{*}$ & 3.954 & .501 \\
\hline $\mathrm{D} \times \mathrm{A} \times \mathrm{Ant}$ & .057 & .036 & .013 \\
\hline$D \times A \times A n t \times G$ & .109 & .912 & 1.420 \\
\hline LxAnt & $9.568^{* *}$ & $36.425^{* * *}$ & $9.18^{* *}$ \\
\hline$L \times$ Ant $\times G$ & 1.857 & $14.587^{* * *}$ & $4.38^{*}$ \\
\hline $\mathrm{D} \times \mathrm{L} \times \mathrm{Ant}$ & .616 & 3.311 & 2.847 \\
\hline $\mathrm{D} \times \mathrm{L} \times \mathrm{Ant} \times \mathrm{G}$ & .379 & .010 & 1.214 \\
\hline$A \times L \times A n t$ & .085 & .975 & .871 \\
\hline$A \times L \times A n t \times G$ & 1.044 & $4.832^{*}$ & 1.506 \\
\hline$D \times A \times L \times A n t$ & .111 & .293 & $5.40^{*}$ \\
\hline$D \times A \times L \times A n t \times G$ & 1.378 & 1.546 & .474 \\
\hline
\end{tabular}

$\mathrm{A}=$ agreement; $\mathrm{D}=$ distance; $\mathrm{L}=$ laterality; $\mathrm{Ant}=$ anteriority; $\mathrm{G}=$ group. ${ }^{*} p<.05,{ }^{* *} p<.01,{ }^{* * *} p<.001$.

하는 부분에서 보다 상세하게 통계적 효과가 의미하는 바를 기술 하였다.

\section{0-200 m}

좌우측 영역 및 전두-후두 영역에서의 시제 표지 간 거리 및 시제 표지 일치 여부에 따른 100-200 ms 구간의 평균진폭에서 집단에 대한 주효과는 유의하지 않았으나, 시제 표지 간 거리에 대한 주효 과는 유의하였다 $\left(F_{(1,28)}=7.270, p<.05\right)$. 즉, 시제 표지 간 근거리의 평균진폭 $(-2.337 \mu \mathrm{V})$ 이 시제 표지 간 원거리의 평균진폭 $(-1.354 \mu \mathrm{V})$ 보다 유의하게 컸다. 또한 전두-후두 영역에 대한주효과도 통계적으
로 유의하였다 $\left(F_{(1,28)}=7.248, p<.05\right)$. 즉, $100-200 \mathrm{~ms}$ 구간에서 전 두 영역의 평균진폭 $(-2.308 \mu \mathrm{V})$ 이 후두 영역의 평균진폭 $(-1.423 \mu \mathrm{V})$ 에 비해 유의하게 크게 나타났다.

시제 표지 간 거리 및 전두-후두 영역 간 이차상호작용이 통계적 으로 유의하였다 $\left(F_{(1,28)}=6.467, p<.05\right)$. 즉, 전두 영역에서의 시제 표지 간 거리에 따른 진폭의 차이가 후두 영역에서의 시제 표지 간 거리에 따른 진폭의 차이에 비해 유의하게 컸다. 좌우측 영역 및 전 두-후두 영역 간 이차상호작용이 통계적으로 유의하였다 $\left(F_{(1,28)}=\right.$ $9.568, p<.01)$. 즉, 전두 영역에서의 좌우측 영역의 진폭 차이가 후 두 영역에서의 좌우측 영역 진폭 차이에 비해 유의하게 컸다. 마지 막으로, 시제 표지 간 거리 및 전두-후두 영역, 집단 간 삼차상호작 용이 통계적으로 유의하였다 $\left(F_{(1,28)}=5.938, p<.05\right)$. 즉, 노년층에서 전두-후두 영역에 따른 시제 표지 간 원거리와 근거리 사이의 평균 진폭의 차이가 청년층에서 전두-후두 영역에 따른 시제 표지 간 먼 거리와 가까운 거리 사이의 평균진폭의 차이에 비해 유의하게 큰 것으로 나타났다.

\section{0-500 ms}

좌우측 영역 및 전두-후두 영역에서의 시제 표지 간 거리 및 시제 표지 일치 여부에 따른 문장판단과제의 300-500 ms 구간의 평균진 폭에서 집단에 대한 주효과는 유의하지 않았으나, 좌우측 영역에 대한 주효과는 유의하였다 $\left(F_{(1,28)}=19.980, p<.001\right)$. 즉, 좌측 영역 의 평균진폭 $(1.589 \mu \mathrm{V})$ 이 우측 영역의 평균진폭 $(0.214 \mu \mathrm{V})$ 에 비해 유의하게 크게 나타났다. 또한 전두-후두 영역에 대한 주효과도 통 계적으로 유의하였다 $\left(F_{(1,28)}=6.290, p<.05\right)$. 즉, 후두 영역의 평균 진폭 $(1.493 \mu \mathrm{V})$ 이 전두 영역의 평균진폭 $(.310 \mu \mathrm{V})$ 에 비해 유의하게 크게 나타났다.

시제 표지 일치 여부 및 좌우측 영역 간 이차상호작용이 통계적 으로 유의하였다 $\left(F_{(1,28)}=11.813, p<.01\right)$. 즉, 시제 표지 간 불일치 조 건에서 좌우측 영역에 따른 진폭 크기의 차이가 시제 표지 간 일치 조건에서의 좌우측 영역에 따른 진폭의 크기의 차이에 비해 유의하 게 컸다. 좌우측 영역 및 전두-후두 영역 간 이차상호작용이 통계적 으로 유의하였다 $\left(F_{(1,28)}=36.425, p<.001\right)$. 즉, 전두 영역에서의 시 제 표지 간 거리에 따른 진폭의 차이가 후두 영역에서의 시제 표지 간 거리에 따른 진폭의 차이에 비해 유의하게 컸다. 좌우측 영역 및 전두-후두 영역, 집단 간 삼차상호작용이 통계적으로 유의하였다 $\left(F_{(1,28)}=14.587, p<.001\right)$. 즉, 노년층에서 좌우측 영역에 따른 전두후두 영역 간 진폭의 차이가 청년층에서 좌우측 영역에 따른 전두후두 영역 간 진폭의 차이에 비해 유의하게 큰 것으로 나타났다. 시 제 표지 간 거리, 좌우측 영역, 전두-후두 영역 및 집단 간 사차상호 
작용이 통계적으로 유의하였다 $\left(F_{(1,28)}=4.832, p<.05\right)$. 즉, 노년층에 서 좌우측 영역 및 전두-후두 영역에 따른 시제 표지 간 원거리와 근거리의 진폭의 차이에 비해 유의하게 큰 것으로 나타났다.

\section{$600-800 \mathrm{~ms}$}

분석 결과, 좌우측 영역 및 전두-후두 영역에서의 시제 표지 간 거리 및 시제 표지 일치 여부에 따른 문장판단과제의 600-800 ms 구간의 평균진폭에서 집단에 대한주효과가 유의하였다 $\left(F_{(1,28)}=8.058\right.$, $p<.01)$. 즉, $600-800 \mathrm{~ms}$ 구간에서 청년층의 평균진폭 $(2.591 \mu \mathrm{V})$ 이 노년층의 평균진폭 $(225 \mu \mathrm{V})$ 에 비해 유의하게 더 큰 것으로 나타났 다. 또한 좌우측 영역에 대한 주효과가 유의하였다 $\left(F_{(1,28)}=18.760\right.$, $p<.001)$. 즉, 좌측 영역의 평균진폭 $(1.918 \mu \mathrm{V})$ 이 우측 영역의 평균 진폭 $(.897 \mu \mathrm{V})$ 에 비해 유의하게 더 컸다.

좌우측 영역 및 전두-후두 영역 간 이차상호작용이 통계적으로 유의하였다 $\left(F_{(1,28)}=9.18, p<.01\right)$. 즉, 우측 영역에서의 전두-후두 영 역 간 진폭의 차이가 좌측 영역에서의 전두-후두 영역 간 진폭의 차 이에 비해 유의하게 컸다. 시제 표지 일치 여부, 거리, 좌우측영역간 삼차상호작용이 통계적으로 유의하였다 $\left(F_{(1,28)}=7.44, p<.05\right)$. 즉, 우측 영역에서의 시제 일치 여부에 따른 시제 표지 간 원거리와 근 거리 간의 진폭의 차이가 좌측 영역에서의 시제 일치 여부에 따른 시제 표지 간 원거리와 근거리 간의 진폭의 차이에 비해 유의하게 크게 나타났다. 또한 좌우측 영역 및 전두-후두 영역, 집단 간 삼차 상호작용이 통계적으로 유의하였다 $\left(F_{(1,28)}=4.38, p<.05\right)$. 즉, 청년 층에서의 좌우측 영역에 따른 전두-후두 영역 간 진폭의 차이가 노 년층에서의 좌우측 영역에 따른 전두-후두 영역 간 진폭의 차이에 비해 유의미하게 컸다. 마지막으로 시제 표지 간 거리, 일치, 좌우측 영역, 전두-후두 영역 사차상호작용이 통계적으로 유의하였다 $\left(F_{(1,}\right.$ $\left.{ }_{28}=5.40, p<.05\right)$. 즉, 시제 표지 불일치 조건에서 좌우측 영역 및 전 두-후두 영역에 따른 시제 표지 간 원거리와 근거리 사이의 진폭의 차이가 시제 표지 일치 조건에서 좌우측 영역 및 전두-후두 영역에 따른 시제 표지 간 원거리와 근거리 사이의 진폭의 차이에 비해 유 의하게 크게 나타났다.

\section{논의 및 결론}

본 연구의 목적은 시제 표지 간 거리 및 시제 표지 일치 여부에 따라 문장판단과제에서 정상 청년층과 노년층 간 정반응률, 반응 시간 및 ERP 성분의 평균진폭(mean amplitude) 크기에서 유의한 차이가 있는지 알아보는 것이다. 문장판단과제에서 정반응률 및 반응시간 모두에서 시제 표지 간 거리에 대한 주효과 및 집단에 대
한 주효과가 공통적으로 유의한 것으로 나타났다. 즉, 시제 부사와 동사간 거리가 멀어질수록 정반응률이 낮아지고 반응시간이 오래 걸리는 것으로 나타났으며, 이는 시제 표지 간 거리가 인지적 부담 을 높여 인지적 용량을 많이 요구하는 요소일 수 있음을 시사한다. 또한, 청년층에 비해 노년층이 모두 유의하게 낮은 수행력을 보임을 알 수 있다. 즉, 시제 처리 과정은 노화에 따른 영향을 받는 요소임 을 확인할 수 있었다. 정반응률에서는 추가적으로 시제 표지 일치 여부에 따른 주효과 또한 유의하였으며, 이는 불일치 조건에서 정 반응률이 유의하게 높은 것에 기인한 결과이다. 이러한 결과는 불 일치 조건에서 언어적 오류가 명시적으로(explicitly) 제시되어 보다 쉽게 오류를 파악할 수 있는 단서가 되어 정반응률이 상승한 것으 로 해석된다.

$\mathrm{ERP}$ 성분에 대한 시간대별 결과를 살펴보면, 자극 제시 후 100$200 \mathrm{~ms}$ 구간에서 우측 및 전두-후두 영역에서 시제 표지 간 거리 및 시제 표지 일치 여부에 따른 목표 단어(critical word)에서의 평균진 폭의 집단에 대한 주효과가 유의하지 않았으나, 시제 표지 간 거리 에 따른 주효과가 유의하였다. 거리에 대한 주효과 현상은 시간 부 사와 동사 시제 표지 간 원거리 조건에서보다 두 가지 시제 표지 간 근거리에서 평균진폭의 부적 방향성이 더 크게 나타난 것에 기인한 다. 이는 한국어에서 특징적으로 나타나는 시제 부사의 위치와 관 련하여 설명될 수 있다. 근거리 조건의 경우, 시제 부사가 동사 바로 앞에 위치하게 된다. 이는 한국어에서 시제 부사와 동사 사이에 목 적격이 위치하는 어순이 보다 전형적인 어순으로 보는 이론(Im, 2009)에 근거할 때 비전형적인 어순에 해당한다. 즉, 한국어의 경우 문장 성분 간 거리 자체가 멀어짐에 따라 인지적 요구 요량이 증가 하는 효과보다 근거리에서 나타나는 부사 위치의 비전형성에 기인 하여 근거리에서 부적 방향성이 출현한 것으로 해석된다. 이는 한국 어가 어순이 자유로운 특징을 가지고 있지만, 부사 위치에 따른 어 순의 전형성이 문장 처리 과정에 영향을 미칠 수 있음을 시사한다.

300-500 ms 구간에서 시제 표지 일치 여부 및 시제 표지 간 거리, 집단 간 유의미한 주효과를 확인할 수 없었다. 그러나 파형에 대한 시각적 분석에 따르면, 청년층의 전체 평균 파형에서 좌전두 영역에 서의 부적 파형을 발견할 수 있었다. 좌전두 영역에서 청년층 평균 파형에서 부적 파형이 나타났으나 시제 표지 일치 여부에 따른 차 이는 크게 나타나지 않았다. 또한 불일치 유형에서 좌전두 영역의 평균 파형을 살펴본 결과 원거리 조건에서 부적 파형을 확인할 수 있었다. 이는 의미적 단서, 즉 시간 부사에 근거하여 동사의 형태를 예상하는 경우 불일치 과제에서 P600 효과와 함께 300-400 ms 구 간에서 부적 파형이 나타난다는 선행연구의 결과와 관련되는 것으 로 볼 수 있다(Dillon et al., 2012). 하지만, 이 구간에서 LAN 효과가 
본 연구에서 통계적으로 명확하게 나타나지 않은 이유는 선행연구 에서 LAN 효과는 구문적 통합에 요구되는 작업기억 용량을 반영 하는 것으로 보았으나, 본 연구에서 시간 부사와 동사의 시제 표지 거리에 따른 용량 요구에 대한 인지적 요소가 300-500 ms 구간에 서는 뇌파에 반영되지 않았을 가능성이 제기된다.

마지막으로, 자극 제시 후 600-800 ms 구간에서 평균진폭의 집 단에 대한 주효과가 유의하였다. 노년층의 평균진폭의 크기가 정적 방향으로 청년층의 평균진폭 크기에 비해 유의하게 작게 나타난 것 에 기인한 결과이다. 이러한 결과는 노년층이 청년층에 비해 진폭 이 낮아지는(attenuated amplitude) 현상을 보인다는 기존 연구와 일치한다(Faustmann, Murdoch, Finnigan, \& Copland, 2007; Federmeier, McLennan, De Ochoa, \& Kutas, 2002; Federmeier \& Kutas, 2005; Gunter, Jackson, \& Mulder, 1995; Kutas \& Iragui, 1998). 노년층의 진폭이 감소하는 현상은, $\mathrm{ERP}$ 의 진폭이 인지적 처리에 개 입되는 노력의 양을 나타낸다는 주장에 근거하여 해석해볼 수 있 다(Matzke, Mai, Nager, Rüsseler, \& Münte, 2002). 노화에 따라 인 지적 용량이 감소하는 현상이 문장이해의 실시간 처리 과정을 살 펴보는 ERP 진폭에도 반영되어 청년층에 비해 뇌파의 형태가 감소 되는 현상이 나타난 것으로 보인다. 이러한 현상은 한국어 사용자 노년층을 대상으로 한 경어법 문장 처리에서 나타나는 ERP 연구 (Oh \& Sung, 2017) 및 생물성과 어순에 따른 실시간 언어처리 연구 (Oh, Sung \& Sim, 2016)에서 또한 확인된 바 있다. 하지만, 노년층의 진폭 감소 현상과 청년층에 비해 ERP 언어 성분이 뚜렷하게 관찰 되지 않는 현상에 대한 해석에는 주의가 요한다. 본 연구의 한계점 으로 연구 실험에 포함된 문항수가 노년층의 피로 효과 및 집중 시 간 제한 등에 의해 청년층 연구에 비해 매우 적은 편이다. 따라서, 행동분석에서 노년층이 청년층에 비해 유의하게 많은 오류율을 보 였던 것을 감안하면, ERP 분석에 포함된 문항수 부족으로 인해 $\mathrm{ERP}$ 파형이 분명하게 나타나지 않았을 가능성을 배제할 수 없다. 하지만, 노년층에서 진폭이 감소하는 현상은 영어권 및 한국어권 사용자에게 반복적으로 관찰되어 왔던 현상인 것을 고려할 때, 단 지 문항수 부족에 따른 한계라고 단정하는 것에도 무리가 있다. 요 약하면, 600-800 ms 구간에서 청년층이 노년층에 비해 강한 정적 방향 파형을 보여 기존의 P600 성분과 유사한 패턴을 보인 반면, 노 년층의 경우 청년층에 비해 P600 효과가 감소된 형태를 보인 것으 로 정리할 수 있다. 즉, 청년층에게 보다 뚜렷하게 관찰된 P600 현상 은 문장의 구문 구조를 통합하고 재분석하는 하는 과정 및 시제 부 사라는 의미적 단서에 근거하여 동사의 시제 표지를 예상하는 과 정에서 요구되는 인지적 노력을 반영하는 것으로 볼 수 있다. 반면, 인지 용량이 감소된 노년층의 경우, 실시간 문장 처리에서 청년층
에 비해 인지적 노력을 할당하는 능력이 저하되었을 가능성을 생 각해볼수 있다.

전체적으로 행동 결과와 ERP 실시간 처리 과정 결과를 요약하 면 다음과 같다. 우선, 행동 결과에서는 정반응률 및 반응시간 모 두에서 노년층이 청년층에 비해 저조한 결과를 보였다. 정반응만 분석한 ERP 결과에서는 $600-800 \mathrm{~ms}$ 구간에서만 노년층이 청년층 에 비해 유의하게 ERP 진폭이 감소하는 현상을 보였다. 이는 노년 층의 인지 용량 감소와 처리속도 저하(slowed processing speed) (Salthouse, 2000)에 기인하는 것으로 해석해볼 수 있다. 즉, 반응시 간이 늦어지고, 실시간 언어처리에서는 후반부(600-800 ms 구간) 에서 청년층과 구분되어 진폭감소가 나타나는 현상은 노년층의 언 어 처리 속도가 늦어지는 현상을 반영하는 것으로 보인다. 시제 표 지 간 거리 및 일치 여부에 대한 효과는 행동 결과에서는 모두 뚜렷 하게 관찰되었으며, $\mathrm{ERP}$ 실시간 처리 과정에서는 거리에 대한 효과 가 초반부(100-200 ms)에서 유의하게 나타났다. 하지만, 이러한 거 리에 대한 주효과는 앞에서도 언급한 바와 같이, 시제 부사와 동사 시제 표지 간의 거리가 멀어짐에 따라 인지적 요구 용량이 증가하 여 나타나는 현상이라기보다는 어순 비전형성에 기인한 것으로 해 석하는 것이 정당해 보인다. 왜냐하면, 원거리에서보다 근거리에서 부적 방향으로 유의한 ERP 성분이 관찰되었기 때문이다. 이는 거 리에 따른 인지적 부담보다 시제 부사가 원거리에서 동사 바로 앞 에 위치하여 비전형적 어순을 취하게 되는 문장 형태가 ELAN 효 과를 유도한 것으로 보인다. 즉, 한국어 언어 처리 과정에서 비전형 적인 부사구의 위치에 따른 효과는 자극 제시 후 100-200 ms에서 매우 빠르게 인지되는 것으로 해석된다.

본 연구의 제한점 및 후속 연구를 위한 제언은 다음과 같다. 첫 째, 집단을 연령에 따라 만 20-39세는 정상 청년층, 만 60-69세는 정 상 노년층으로 나누어 연구를 실시하였으며, 중장년층을 포함하지 않았다. 국부성 효과(locality effects)에 따른 시제 표지 처리 과정 이 연령에 따라 변화하는 양상을 알아보기 위해 다양한 연령대를 대상으로 한 후속연구가 진행될 필요가 있다. 둘째, 본 연구에서는 문장 성분 간 거리에 따른 시제 표지 처리 과정에 관련한 ERP 성분 으로 P600과 LAN 성분을 분석하였다. 문장 성분 간 거리에 따른 시제 표지 및 문장 처리 과정을 정확하게 살펴보기 위해서는 본 연 구에서 시제 부사와 동사 사이에 제시된 모든 어절을 대상으로 분 석이 이루어질 필요가 있다. 시제 부사에서 마지막 동사까지 요구되 는 작업기억 용량 및 의미·통사적 처리 과정이 평균 파형 및 진폭에 어떻게 나타나는지, 시제 부사와 동사 사이에 위치한 모든 문장 구 성 성분에서 지속적으로 작업기억 관련 ERP 성분이 나타나는지 청년층 및 노년층 집단 간 비교를 통해 살펴볼 필요가 있다. 셋째, 
한국어 사용자 노년층을 대상으로 한 연구가 매우 제한적으로 이 루어지고 있어, 노년층의 집중 시간 및 피로 효과를 고려하여 조건 당 문항수가 매우 제한적이었다는 단점이 있다. 향후 연구에서는 조건에 따른 문항수를 확보할 수 있는 방법을 고려할 필요가 있다. 마지막으로, 본 연구결과 해석에서 뇌영역과 관련된 해석은 논의에 서 자제하였다. 이는 특정 뇌파가 관찰된 뇌영역이 그 뇌파를 발생 시킨 원인으로 해석하는 데 무리가 있기 때문이다. 뇌영역과 관련 된 부분은 추후 Source Analysis 분석 방법을 적용하여 보다 상세 하게 살펴본 후 깊이 있는 논의를 전개할 수 있기를 기대한다.

본 연구는 한국어 사용자 노년층을 대상으로 청년층에 비해 시 제 표지 간 거리 및 일치 여부를 조절하였을 때 오프라인 행동 결과 와 온라인 뇌파 분석 결과에서 어떠한 차이가 있는지를 살펴본 연 구로서, 다양한 한계 및 제한점에도 불구하고 시제 표지에서 나타 나는 한국어 현상을 노년층에서 살펴보았다는 점에서 의의가 있 다. 하지만, 본 연구의 한계점을 보완하여 향후 연구에서는 보다 심 도 있게 한국어에 나타나는 다양한 현상을 노화와 관련된 언어 지 표로서 기능할 수 있는지에 대한 노력이 필요할 것으로 보인다. 나 아가 정상적 노화와 치매 등의 고위험군을 구분하는 데 중요한 언 어 지표 추적 연구로 발전시키는 데 기초연구 자료로서 기능할 수 있다는 측면에서 본 논문의 의의가 있다.

\section{REFERENCES}

Allen, M., Badecker, W., \& Osterhout, L. (2003). Morphological analysis in sentence processing: an ERP study. Language and Cognitive Processes, 18, 405-430.

Angrilli, A., Penolazzi, B., Vespignani, F., De Vincenzi, M., Job, R., Ciccarelli, L., ... \& Stegagno, L. (2002). Cortical brain responses to semantic incongruity and syntactic violation in Italian language: an event-related potential study. Neuroscience Letters, 322, 5-8.

Baggio, G. (2008). Processing temporal constraints: an ERP study. Language Learning, 58(s1), 35-55.

Balota, D. A., Dolan, P. O., \& Duchek, J. M. (2000). Memory changes in healthy older adults. In E. Tulving \& F. I. M. Craik (Eds.), The Oxford handbook of memory (pp. 395-409). Oxford: Oxford University Press.

Barber, H., \& Carreiras, M. (2005). Grammatical gender and number agreement in Spanish: an ERP comparison. Journal of Cognitive Neuroscience, $17,137-153$.

Bayles, K. A., Tomoeda, C. K., Kaszniak, A. W., Stern, L. Z., \& Eagans, K. K. (1985). Verbal perseveration of dementia patients. Brain and Language,
$25,102-116$.

Belmore, S. M. (1981). Age-related changes in processing explicit and implicit language. Journal of Gerontology, 36, 316-322.

Berndt, R. S., Mitchum, C. C., Haendiges, A. N., \& Sandson, J. (1997). Verb retrieval in aphasia. 1. Characterizing single word impairments. Brain and Language, 56, 68-106.

Burke, D. M., \& MacKay, D. G. (1997). Memory, language, and ageing. Philosophical Transactions of the Royal Society B: Biological Sciences, 352, 18451856.

Caplan, D., \& Waters, G. (2005). The relationship between age, processing speed, working memory capacity, and language comprehension. Memory, $13,403-413$.

Caplan, D., DeDe, G., Waters, G., Michaud, J., \& Tripodis, Y. (2011). Effects of age, speed of processing, and working memory on comprehension of sentences with relative clauses. Psychology and Aging, 26, 439-450.

Cohen, G. (1979). Language comprehension in old age. Cognitive Psychology, $11,412-429$.

Comrie, B. (1985). Tense. Cambridge: Cambridge University Press.

Crystal, D. (1966). Specification and English tenses. Journal of Linguistics, 2, $1-34$.

Dillon, B., Nevins, A., Austin, A. C., \& Phillips, C. (2012). Syntactic and semantic predictors of tense in Hindi: an ERP investigation. Language and Cognitive Processes, 27, 313-344.

Faroqi-Shah, Y., \& Thompson, C. K. (2007). Verb inflections in agrammatic aphasia: encoding of tense features. Journal of Memory and Language, 56, 129-151.

Faustmann, A., Murdoch, B. E., Finnigan, S. P., \& Copland, D. A. (2007). Effects of advancing age on the processing of semantic anomalies in adults: evidence from event-related brain potentials. Experimental Aging Research, $33,439-460$.

Featherston, S., Gross, M., Münte, T. F., \& Clahsen, H. (2000). Brain potentials in the processing of complex sentences: an ERP study of control and raising constructions. Journal of Psycholinguistic Research, 29, 141-154.

Federmeier, K. D., \& Kutas, M. (2005). Aging in context: age-related changes in context use during language comprehension. Psychophysiology, 42, 133141.

Federmeier, K. D., McLennan, D. B., De Ochoa, E., \& Kutas, M. (2002). The impact of semantic memory organization and sentence context information on spoken language processing by younger and older adults: an ERP study. Psychophysiology, 39, 133-146. 
Fonteneau, E., Frauenfelder, U. H., \& Rizzi, L. (1998). On the contribution of ERPs to the study of language comprehension. Bulletin suisse de linguistique appliquée, (68), 111-124.

Friederici, A. D. (2002). Towards a neural basis of auditory sentence processing. Trends in Cognitive Sciences, 6, 78-84.

Gallagher, M. (1970). Adverbs of time and tense. Paper at the 6th Regional Meeting of the Chicago Linguistics Society, Chicago, IL.

Gibson, E. (2000). The dependency locality theory: a distance-based theory of linguistic complexity. In A. P. Marantz et al. (Eds), Image, language, brain (pp. 95-126). Cambridge, MA: MIT Press.

Gibson, E., \& Warren, T. (1998). The psychological reality of intermediate linguistic structure in long-distance extractions. Paper presented at the 11th Annual CUNY Conference on Human Sentence Processing, New Brunswick, NJ.

Gouvea, A. C. D. S. L. (2003). Processing syntactic complexity: cross-linguistic differences and ERP evidence (Doctoral dissertation). University of Maryland, College Park, MD.

Gunter, T. C., Jackson, J. L., \& Mulder, G. (1995). Language, memory, and aging: an electrophysiological exploration of the N400 during reading of memory-demanding sentences. Psychophysiology, 32, 215-229.

Hagoort, P., \& Brown, C. M. (2000). ERP effects of listening to speech compared to reading: the P600/SPS to syntactic violations in spoken sentences and rapid serial visual presentation. Neuropsychologia, 38, 1531-1549.

Im, H. S. (2009). A typological study on word orders among the Korean, Russian, English languages: with the focus on the positions of adverbs. Journal of Central and East European Studies, 11, 37-59.

Jasper, H. (1958). Report of the committee on methods of clinical examination in electroencephalography. Electroencephalogr Clin Neurophysiol, 10, 370-375.

Jo, M., Choi, S., \& Hwang, M. (2014). The comprehension and production of tense markings in language delayed children and typically developing children. Phonetics and Speech Sciences, 6, 123-131.

Kaan, E., Harris, A., Gibson, E., \& Holcomb, P. (2000). The P600 as an index of syntactic integration difficulty. Language and Cognitive Processes, 15, 159-201.

Kang, Y., \& Na, D. L. (2003). Seoul Neuropsychological Screening Battery. Seoul: Human Brain Research \& Consulting Co.

Kang, Y., Na, D. L., \& Hahn, S. (1997). A validity study on the Korean MiniMental State Examination (K-MMSE) in dementia patients. Journal of the Korean Neurological Association, 15, 300-308.
Kemtes, K. A., \& Kemper, S. (1997). Younger and older adults' on-line processing of syntactically ambiguous sentences. Psychology and Aging, 12, 362-371.

Kim, M., \& Thompson, C. K. (2000). Patterns of comprehension and production of nouns and verbs in agrammatism: implications for lexical organization. Brain and Language, 74, 1-25.

Kim, M., \& Thompson, C. K. (2004). Verb deficits in Alzheimer's disease and agrammatism: implications for lexical organization. Brain and Language, 88, 1-20.

Kim, S. M. (2013). Tense comprehension in aphasic patients according to the presence of temporal adverb (Master's thesis). Wonkwang University, Iksan, Korea.

Kiparsky, P. (1968). Tense and mood in Indo-European syntax. Foundations of Language, 4, 30-57.

Kluender, R., \& Kutas, M. (1993). Bridging the gap: evidence from ERPs on the processing of unbounded dependencies. Journal of Cognitive Neuroscience, 5, 196-214.

Konieczny, L. (2000). Locality and parsing complexity. Journal of Psycholinguistic Research, 29, 627-645.

Kutas, M., \& Hillyard, S. A. (1983). Event-related brain potentials to grammatical errors and semantic anomalies. Memory \& Cognition, 11, 539-550.

Kutas, M., \& Iragui, V. (1998). The N400 in a semantic categorization task across 6 decades. Electroencephalography and Clinical Neurophysiology/ Evoked Potentials Section, 108, 456-471.

Lee, J., Kwon, M., Na, H. R., Bastiaanse, R., \& Thompson, C. K. (2013). Production and comprehension of time reference in Korean nonfluent aphasia. Communication Sciences \& Disorders, 18, 139-151.

Leinonen, A., Brattico, P., Järvenpää, M., \& Krause, C. M. (2008). Event-related potential (ERP) responses to violations of inflectional and derivational rules of Finnish. Brain Research, 1218, 181-193.

Levy, R. P., \& Keller, F. (2013). Expectation and locality effects in German verbfinal structures. Journal of Memory and Language, 68, 199-222.

Luck, S. J. (2014). An introduction to the event-related potential technique. Cambridge, MA: MIT Press.

Luzzatti, C., Raggi, R., Zonca, G., Pistarini, C., Contardi, A., \& Pinna, G. D. (2002). Verb-noun double dissociation in aphasic lexical impairments: the role of word frequency and imageability. Brain and Language, 81, 432444 .

Martin, S. E. (1992). A reference grammar of Korean: a complete guide to the grammar and history of the Korean language. Tokyo: Tuttle Publishing. 
Mätzig, S., Druks, J., Masterson, J., \& Vigliocco, G. (2009). Noun and verb differences in picture naming: past studies and new evidence. Cortex, 45 , 738-758.

Matzke, M., Mai, H., Nager, W., Rüsseler, J., \& Münte, T. (2002). The costs of freedom: an ERP-study of non-canonical sentences. Clinical Neurophysiology, 113, 844-852.

Ministry of Education. (1997). Korean high school grammar. Seoul: Korea textbook company limited.

Nam, Y., \& Hong, U. (2013). Constituent length and word order preference in language production. Korean Journal of Cognitive Science, 24, 25-47.

Oh, S. J., \& Sung, J. E. (2017). Age-related differences in ERP components during Korean honorific sentence processing depending on listener's social status and predicate agreement. Communication Sciences \& Disorders, 22, 101-116.

Oh, S. J., Sung, J. E., \& Sim, H. S. (2016). Age-Related differences in animacy effects as a function of word-order canonicity in a verb-final language: evidence from ERP. Communication Sciences \& Disorders, 21, 653-667.

Osterhout, L., \& Mobley, L. A. (1995). Event-related brain potentials elicited by failure to agree. Journal of Memory and Language, 34, 739-773.

Phillips, C., Kazanina, N., \& Abada, S. H. (2005). ERP effects of the processing of syntactic long-distance dependencies. Cognitive Brain Research, 22, 407-428.

Roehm, D., Bornkessel, I., Haider, H., \& Schlesewsky, M. (2005). When case meets agreement: event-related potential effects for morphology-based conflict resolution in human language comprehension. NeuroReport, 16, 875-878.

Salthouse, T. A. (2000). Aging and measures of processing speed. Biological
Psychology, 54, 35-54.

Sohn, H. M. (1999). The Korean language. Cambridge: Cambridge University Press.

Steinhauer, K., \& Ullman, M. T. (2002). Consecutive ERP effects of morphophonology and morpho-syntax. Brain and Language, 83, 62-65.

Stine-Morrow, E. A. L., Ryan, S., \& Leonard, J. S. (2000). Age differences in on-line syntactic processing. Experimental Aging Research, 26, 315-322.

Streb, J., Rösler, F., \& Hennighausen, E. (1999). Event-related responses to pronoun and proper name anaphors in parallel and nonparallel discourse structures. Brain and Language, 70, 273-286.

Sung, J. E. (2015). Age-related changes in sentence production abilities and their relation to working-memory capacity: evidence from a verb-final language. PLoS One, 10, e0119424.

Sung, J. E., \& Kwag, E. J. (2012). Age-related verb naming abilities depending on the argument structures. Korean Journal of Communication \& Disorders, $17,550-564$.

Watkins, M., Gordon, W., \& Jeffries, A. (1998). The sentence of the court: $a$ handbook for magistrates. Hook, UK: Waterside Press.

Woo, I. H. (1991). Korean tense production and time adverb. Journal of Korean Language and Culture, 9, 161-200.

Yeom, T. H., Park, Y. S., Oh, K. J., Kim, J. K., \& Lee, Y. H. (1992). Korean Wechsler Adult Intelligence Scale (K-WAIS). Seoul: Guidance Korea.

Zingeser, L. B., \& Berndt, R. S. (1990). Retrieval of nouns and verbs in agrammatism and anomia. Brain and Language, 39, 14-32.

Zurif, E., Swinney, D., Prather, P., Wingfield, A., \& Brownell, H. (1995). The allocation of memory resources during sentence comprehension: evidence from the elderly. Journal of Psycholinguistic Research, 24, 165-182. 
Appendix 1. Stimuli sentences

\begin{tabular}{|c|c|c|c|}
\hline \multicolumn{2}{|c|}{ Tense reference between long distance } & \multicolumn{2}{|c|}{ Tense reference between short distance } \\
\hline Agree & Disagree & Agree & Disagree \\
\hline 어제 여자가 아이를 업었다. & 어제 여자가 아이를 업을 것이다. & 여자가 아이를 어제 업었다. & 여자가 아이를 어제 업을 것이다. \\
\hline 이따가 여자가 아이를 업을 것이다. & 이따가 여자가 아이를 업었다. & 여자가 아이를 이따가 업을 것이다. & 여자가 아이를 이따가 업었다. \\
\hline 어제 여자가 접시를 던졌다. & 어제 여자가 접시를 던질 것이다. & 남자가 접시를 어제 던졌다. & 남자가 접시를 어제 던질 것이다. \\
\hline 내일 남자가 접시를 던질 것이다. & 내일 남자가 접시를 던졌다. & 남자가 접시를 내일 던질 것이다. & 남자가 접시를 내일 던졌다. \\
\hline 아까 여자가 소금을 뿌렸다. & 아까 여자가 소금을 뿌릴 것이다. & 여자가 소금을 아까 뿌렸다. & 여자가 소금을 아까 뿌릴 것이다. \\
\hline 이따가 여자가 소금을 뿌릴 것이다. & 이따가 여자가 소금을 뿌렸다. & 여자가 소금을 이따가 뿌릴 것이다. & 여자가 소금을 이따가 뿌렸다. \\
\hline 아까 남자는 상자를 실었다. & 아까 남자는 상자를 실을 것이다. & 남자는 상자를 아까 실었다. & 남자는 상자를 아까 실을 것이다. \\
\hline 이따가 남자는 상자를 실을 것이다. & 이따가 남자는 상자를 실었다. & 남자는 상자를 이따가 실을 것이다. & 남자는 상자를 이따가 실었다. \\
\hline 아까 여자가 휴지를 넣었다. & 아까 여자가 휴지를 넣을 것이다. & 여자가 휴지를 아까 넣었다. & 여자가 휴지를 아까 넣을 것이다. \\
\hline 내일 여자가 휴지를 넣을 것이다. & 내일 여자가 휴지를 넣었다. & 여자가 휴지를 내일 넣을 것이다. & 여자가 휴지를 내일 넣었다. \\
\hline 어제 남자가 신문을 놓았다. & 어제 남자가 신문을 놓을 것이다. & 남자가 신문을 이따가 놓을 것이다. & 남자가 신문을 이따가 놓았다. \\
\hline 내일 남자가 접시를 던질 것이다. & 내일 남자가 접시를 던졌다. & 남자가 접시를 내일 던질 것이다. & 남자가 접시를 내일 던졌다. \\
\hline 어제 여자가 깃발을 꽂았다. & 어제 여자가 깃발을 꽂을 것이다. & 여자가 깃발을 어제 꽂았다. & 남자가 깃발을 어제 꽃을 것이다. \\
\hline 내일 여자가 깃발을 꽃을 것이다. & 내일 여자가 깃발을 꽃았다. & 여자가 깃발을 내일 꽃을 것이다. & 여자가 깃발을 내일 꽃았다. \\
\hline 아까 남자가 신문을 놓았다. & 아까 남자가 신문을 놓을 것이다. & 남자가 신문을 아까 놓았다. & 남자가 신문을 아까 놓을 것이다. \\
\hline
\end{tabular}




\section{국문초록}

\section{문장 성분 간 거리에 따른 시제 표지 처리 과정에 대한 청년층 및 노년층의 ERP 성분 비교 김지인 · 성지은 · 이수은 · 심현섭 \\ 이화여자대학교 언어병리학과}

배경 및 목적: 본 연구는 문장 성분 간 시제 표지 처리 과정에서 청년층과 노년층 간 연령에 따른 차이를 살펴보고자 하였다. 방법: 정상 청년층 15 명, 정상 노년층 17 명으로 총 32 명이 참여하였다. 시제 표지 간 거리는 시제 부사와 동사간의 거리로 정의하며, 근거리 및 원거 리 두 가지 조건으로 구성하였다. 또한, 시제 표지 간 일치 여부를 조절하여 일치 및 불일치 조건을 추가하여, 총 4 가지 조건으로 실험이 제시되었다. 이프라임(E-Prime 2.0) 및 BrainAmp Standard, actiCAP을 사용하여 행동 데이터 및 뇌파를 기록하였다. 결과: 문장판단 과제 정확도 및 반응시간에서 노년층이 청년층에 비해 유의하게 저조한 수행력을 보였다. ERP 분석 결과, P600 성분에서 집단 간 차이 가 유의하였다. 즉, 노년층에서 청년층에 비해 유의하게 평균진폭이 감소되었다. 논의 및 결론: 노년층에서 시제 표지 처리 과정에서 요 구되는 문장의 구문 구조 통합 및 재분석하는 처리 능력이 저하되었음을 알 수 있었다. 노년층에서 ERP 진폭의 감소가 나타난 것은 인 지 용량 감소 및 처리속도 저하에 기인한 것으로 해석된다. 인지적 부담에 따른 노년층 문장처리 능력을 시제 표지 간 거리 및 실시간 처 리 과정 패러다임을 통해살펴보았다는 점에서 의미가 있다.

핵심어: 시제 표지, 문장 성분 간 거리, 사건관련전위(ERP), 노화

본 연구는 2017년 대한민국 교육부와 한국연구재단의 지원을 받아 수행된 연구임(No. NRF-2017R1A2B4006604).

\section{참고문헌}

강연욱, 나덕렬(2003). 서울신경심리검사(Seoul Neuropsychological Screening Battery). 서울: 휴브알엔씨. 강연욱, 나덕렬, 한승혜(1997). 치매환자들을 대상으로 한 K-MMSE의 타당도연구. 대한신경과학회지, 15, 300-308.

교육부. (1997). 고등학교 문법. 서울: 대한 교과서 주식회사.

김수미(2013). 시간부사 유무에 따른 실어증 환자의 시제이해. 원광대학교 대학원 석사학위논문.

남윤주, 홍우평(2013). 언어산출에서 문장성분의 길이가 어순에 미치는 영향. 인지과학, 24, 25-47.

성지은, 곽은정(2012). 연령 및 동사 논항 구조에 따른 애니메이션을 활용한 동사 이름대기 과제 수행력 차이. 언어청각장애연구, 17, 550-564.

염태호, 박영숙, 오경자, 김정규, 이영호(1992). 한국판 웩슬러 성인용 지능 검사(K-WAIS): 실시 요강. 서울: 한국가이던스.

오선정, 성지은(2017). 청자-화자 지위관계 및 종결어미 일치 여부에 따라 경어법 문장처리과정에서 나타나는 청년층 및 노년층 간 ERP 성분 차이 분

석. 언어청각장애연구, 22, 101-116.

오세진, 성지은, 심현섭(2016). 한국어 문장처리에서 나타나는 어순 전형성에 따른 생물성 효과 연구: 청년층 및 노년층의 ERP 성분 비교 분석. 언어청

각장애연구, 21, 653-667.

우인혜(1991). 우리말 시제/상 표현과 시간 부사. 한국언어문화, 9, 161-200.

임흥수(2009). 한국어, 러시아어, 영어 어순의 유형론. 동유럽발칸학, 11,37-59.

조미옥, 최소영, 황민아(2014). 언어발달지체아동과 일반아동의 시제 표지 이해 및 산출 특성. 말소리와음성과학, 6, 123-131. 